\title{
Laparoscopic Cholecystectomy in Cirrhotic Patients: A Retrospective Study
}

\author{
Mohammed Alabed Alhamid ${ }^{1,2}, V$ lad-Costin Ilie $^{3}$, Sanziana Aioanei ${ }^{3}$, Oana Stanciulea ${ }^{3}$, Corina-Elena Minciuna ${ }^{13^{*}}$, \\ Monica Lacatus ${ }^{1,3}$
}

"Carol Davila" University of Medicine and Pharmacy, Bucharest, Romania

${ }^{2}$ Department of General Surgery, King Fahad Hospital, Albaha, Saudi Arabia

${ }^{3}$ Department of General Surgery, Fundeni Clinical Institute, Bucharest, Romania

${ }^{*}$ Corresponding author:

Corina-Elena Minciuna, MD

General Surgery Department

Fundeni Clinical Institute,

258 Fundeni Street, Bucharest,

Romania

E-mail: corinaminciuna01@gmail.com

\section{Rezumat}

Colecistectomia laparoscopică la pacientul cirotic: un studiu retrospectiv

Introducere: Ciroza reprezintă o cauză importantă de mortalitate şi morbiditate la nivel global. Deşi pacientul cu ciroză prezintă riscuri crescute în cazul intervențiilor chirurgicale, anumite afecțiuni, cum ar fi colecistita litiazică nu pot fi tratate altfel. Scopul acestui studiu este reprezentat de evaluarea parametrilor preoperatori ai pacienților cirotici cu colecistită litiazică şi a unei posibile corelații între acestea şi complicațiile postoperatorii estimate prin clasificarea Dindo-Clavien.

Materiale şi Metode:Acesta este un studiu retrospectiv. Cazurile au fost selectate din baza de date a Departamentului de Chirurgie Generală din cadrul Institutului Clinic Fundeni, în perioada 20142018, utilizând ca şi cuvinte cheie următoarea asociere: „,ciroza” şi „colecistita”. Din 57 de cazuri inițiale au fost excluse 3 datorită rezecțiilor asociate.

Rezultate:Studiul a identificat o corelatie pozitivă între clasificarea Dindo-Clavien şi următoarele variabile: abordul deschis (0.405, $\mathrm{p}=0.002)$, intervenția chirurgicală de urgență $(0.599, \mathrm{p}=0.000)$, colecistita acută $(.476, \mathrm{p}=0.000)$, scorul MELD $(0.291, \mathrm{p}=0.008)$ şi scorul Child (0.346, p=0.007), bilirubina totală $(0.220, p=0.047)$, INR (0.286, $\mathrm{p}=0.010)$, prezența lichidului de ascită $(0.303, \mathrm{p}=0.022)$ şi a semnelor de hipertensiune portală $(0.266, p=0.044)$; de asemenea s-a identificat o corelație negativă între morbiditate şi valoarea preoperatorie a hemoglobinei $(-0.295, \mathrm{p}=0.044)$.

Concluzii: Estimarea adecvată a morbidității şi mortalității perioperatorii este în general limitată de natura retrospectivă a 
majorității studiilor existente şi de criteriile de selecție ale pacienților. Chirurgia de urgență, diagnosticul de colecistită acută şi abordul deschis prezintă risc de morbiditate şi mortalitate postoperatorii crescute.

Cuvinte cheie: ciroză, colecistită, laparoscopie, Child-Pugh, MELD

\begin{abstract}
Introduction: Cirrhosis is a leading cause of morbidity and mortality around the world. Although cirrhotic patients are considered to have a higher risk for surgical procedures than non-cirrhotic ones, there are certain pathologies such as gallstones cholecystitis that cannot be treated otherwise. The focus of this study is to evaluate the main characteristics of the patients with lithiasic cholecystitis and liver cirrhosis and to assess if there is a correlation between them and postoperative morbidity evaluated with Dindo-Clavien classification.

Material and methods: This is a retrospective study. The database from General Surgery Department of Fundeni Clinical Institute was queried between 2014-2018 using as key words "cirrhosis" and "cholecystitis". The initial interrogation reveled 57 cases out of which 3 were excluded since other resections were associated.

Results: This study identified that Dindo-Clavien classification positively correlates with the open approach $(0.405, \mathrm{p}=0.002)$, emergency surgery $(0.599, \mathrm{p}=0.000)$, acute cholecystitis $(0.476$, $\mathrm{p}=0.000)$, high MELD score $(0.291, \mathrm{p}=0.008)$ and Child score $(0.346, \mathrm{p}=0.007)$ and furthermore with high levels of total bilirubin $(0.220, p=0.047)$, high INR $(0.286, p=0.010)$, the presence of ascites $(0.303, \mathrm{p}=0.022)$ and portal hypertension $(0.266, \mathrm{p}=0.044)$. It also correlates negatively with the levels of hemoglobin $(-0.295, \mathrm{p}=0.044)$.

Conclusion: Adequate estimation of perioperative mortality and morbidity is generally limited by the retrospective nature of most studies and the patient's selection criteria. Emergency surgery, acute cholecystitis and the open approach carry the highest risk for unfavorable results of cholecystectomy in cirrhotic patients.
\end{abstract}

Key words: cirrhosis, cholecystitis, laparoscopy, Child-Pugh, MELD

\section{Introduction}

Cirrhosis is a leading cause of morbidity and mortality around the world, the annual death rate from liver cirrhosis in Europe being around 170,000 (1,2). Although cirrhotic patients are considered to have a higher surgical risk than non-cirrhotic ones, there are certain pathologies that cannot be treated otherwise. Gallstone prevalence in patients with liver cirrhosis is at least twice that in the general population, ranging between $25 \%$ and $30 \%$, and it usually develops after a longer duration of cirrhosis (3). Therefore, cholecystectomy is the most common surgical procedure performed on cirrhotic patients, with known complications such as perioperative bleeding, hepatic failure, kidney failure, postoperative infection, and impaired wound closure (2). Consequently, there is a consensus that only patients with symptomatic gallstones should undergo surgery (4). Laparoscopic cholecystectomy appears to be an effective and safe procedure for patients with Child-Pugh class A or B, with shorter operative time, reduced complication rates and shorter hospital stay, but there are few data regarding patients with Child-Pugh class $\mathrm{C}$ cirrhosis (5-7). The focus of this study is to assess the main characteristics of the 
patients with lithiasic cholecystitis and cirrhosis and to evaluate if there is a correlation between some variables and postoperative morbidity evaluated with DindoClavien classification.

\section{Material and Methods}

\section{Data Source and Patient Selection}

This is a retrospective study. The database from General Surgery Department, Fundeni Clinical Institute was queried between 2014-2018 using as key words "cirrhosis" and "cholecystitis". The initial interrogation reveled 57 cases out of which 3 were excluded since other resections were associated. The following parameters were evaluated: age, gender, comorbidities, the etiology of the cirrhosis, number of days to surgery and postoperative in hospital stay, ASA score, grade of urgency, the type of cholecystitis (acute or chronic), the type of approach (open or laparocopic), if choledocholithiasis was associated, Child-Pugh score, MELD score, if dialysis is performed, presence of portal hypertension. Assessed bioumoral markers included: total bilirubin, albumin, fibrinogen, INR, aPTT, GGT, ALT, AST, Na, K, Cl, Ca, creatinine, leukocyte, hemoglobin and thrombocytes.

\section{Statistical Analysis}

The statistical analysis was performed with IBM SPSS Statistics for Windows (version 23.0, IBM, Chicago, IL) and Microsoft Excel. Continuous variables were presented as mean \pm standard deviation or median and range after checking for normality. Categorical variables were described in frequencies and percentages. Kendall's tau_b Correlation Coefficient and Spearman's Rho was used to assess correlations between different variables. For all analyses, $p$-values less than 0.05 were considered statistically significant.

\section{Results}

The mean age was of 58 years old with a minimum of 46 and maximum of 80 years. In what concerns the gender distribution, the study shows that $49 \%$ of the patients were males. Only $23 \%$ had no known comorbidities, except cirrhosis.

Evaluating the etiology of the cirrhosis, the study concludes, as described in Fig. 1, that predominantly $41 \%$ of the cases were hepatitis $\mathrm{C}$ virus (VHC), followed by chronic alcohol abuse (TN) $30 \%$ and hepatitis $\mathrm{B}$ virus (VHB) 11\%. Other causes of cirrhosis were the association between VHB and hepatitis D virus (VHD) $8 \%$, cryptogenic $6 \%$ and in $4 \%$ of cases VHB and VHC.

Within the studied group, the ASA score varies between 2 and 4 , most patients having a score of $3(43 \%)$, while the rest are divided equally between ASA 2 and 4, each comprising $28 \%$ of the patients.

Assessment of cirrhosis severity was performed using the Child-Pugh and MELD score. $72 \%$ of patients were in class A of ChildPugh score, 21\% in Child-Pugh B and only 8\% in $\mathrm{C}$. The average value of the MELD score was 10.9 with a minimum of 1.05 and a maximum of 25.5 .

$32 \%$ of patients showed signs of portal hypertension, of which $19 \%$ associated ascites at the time of diagnosis. These patients required preoperative treatment to optimize hemodynamics and metabolic derangements. Only one patient was on dialysis and there were no patients with encephalopathy at the moment of diagnosis.

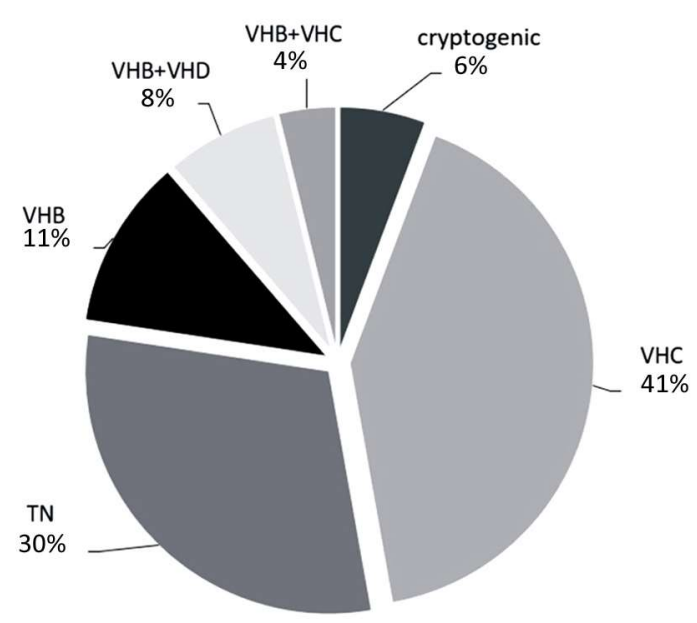

Figure 1. Percentage of cases according to cirrhosis etiology 
$28 \%$ of patients underwent emergency surgery, although $42 \%$ were diagnosed with a form of acute cholecystitis. The minimally invasive approach was preferred by most surgeons $(72 \%)$ with a conversion rate of $7 \%$. Only two patients (4\%) associated choledocholithiasis for which endoscopic retrograde cholangiopancreatography (ERCP) with stone extraction was performed preoperatively.

Postoperative complications were evaluated using Dindo-Clavien classification. No reintervention was recorded, and $64 \%$ of patients had an uneventful course. $23 \%$ developed minor complications Dindo-Clavien 1 and 2, which were mostly conservatively managed; only two patients $(4 \%)$ required percutaneous drainage of intra-abdominal collections. Five patients (2 Child B, 2 Child C and one Child A), representing $9 \%$ of the cases, died. All were diagnosed with acute cholecystitis and had other important comorbidities (neoplasia, decompensated cardiovascular diseases, etc.).

The mean preoperative number of days was 4.7 days varying between 0 and 14 days. Postoperative hospitalization was on average 7 days with a minimum of 3 and a maximum of 15 days.

\section{Discussions}

The vast majority of the studies evaluating biliary surgery in cirrhotic patients focus on lithiasic cholecystitis. The incidence of cholelithiasis in cirrhotic patients is twice as high as in patients without cirrhosis $(8,9)$. Among the pathogenic factors responsible for lithogenesis in this particular group are implicated: hemolysis, hypersplenism, decreased concentration of bile acids, metabolic liver failure which leads to an increased unconjugated bilirubin blood level and dysregulation of gallbladder function (10). Surgery in the cirrhotic patient has always been a controversial topic, with limited indications due to increased risk of intraoperative accidents and postoperative complications. The surgical decision for cholecystectomy in cirrhotic patients should be carefully evaluated due to the risks of liver failure and severe bleeding, especially in those with overt clinical portal hypertension syndrome. Moreover, cirrhosis is the leading cause of death after biliary tract surgery (11) with a mortality after open surgery that can reach $7-15 \%$ (12) in contrast to the mortality of normal patients of $0.5-1 \%$ (9). The mortality recorded in this study is of $9.4 \%$ within the data reported in the literature.

Initial literature data showed high rates of morbidity and mortality after laparoscopic cholecystectomy (13-15). Subsequently, a meta-analysis based on 25 previous publications established the superiority of laparoscopic approach in terms of operative time, intraoperative bleeding, and postoperative hospitalization in patients with Child A and $\mathrm{B}$ cirrhosis. Cirrhotic patients were more frequently treated in the emergency department (47\% with acute cholecystitis compared to $17.7 \%$ in non-cirrhotic patients) and had higher morbidity rates $(20.86 \%$ versus $7.99 \%$ ). $28 \%$ of patients in the evaluated group underwent emergency surgery. Child $\mathrm{C}$ patients ought to undergo conservative treatment, or if necessary, percutaneous cholecystostomy may be considered (16). These data are consistent with the results published by Curro et al which reports a morbidity of $75 \%$ and mortality of $50 \%$ in Child C patients (17). The ASA score positively corelate with DindoClavien classification and the number of postoperative days as showed in Table 1 .

The data of a study conducted over a period of 16 years (1994-2011) indicates superior results to those previous published; they could be due, on one hand to the technological progress and the use of hemostatic materials and on the other hand to subtotal cholecystectomy performed in patients with difficult dissection and high risk of bleeding. The overall conversion rate was $4.58 \%$, morbidity $17 \%$ and mortality $0.45 \%$ (18). This study reports a conversion rate of $7.4 \%$, morbidity $35.8 \%$ and mortality of $9.4 \%$.

Delis S. et al evaluated a possible correlation of Child score and MELD score with the 
Table 1. Kendall's tau_b Correlation Coefficient for ASA Score

\begin{tabular}{|c|c|c|c|c|c|c|c|c|c|c|c|c|}
\hline \multicolumn{2}{|c|}{ Kendall's tau_b } & \multirow{2}{*}{$\begin{array}{c}\begin{array}{c}\text { Post } \\
\text { operative } \\
\text { days }\end{array} \\
.306^{\star \star}\end{array}$} & \multirow{2}{*}{$\begin{array}{c}\begin{array}{c}\text { Dindo } \\
\text { Clavien } \\
\text { Classif. }\end{array} \\
370^{\star \star}\end{array}$} & \multirow{2}{*}{$\begin{array}{c}\begin{array}{c}\text { Surgical } \\
\text { approach }\end{array} \\
.316^{\star}\end{array}$} & \multirow{2}{*}{$\begin{array}{c}\begin{array}{c}\text { Elective/ } \\
\text { Emergency } \\
\text { surgery }\end{array} \\
.368^{\star \star}\end{array}$} & \multirow{2}{*}{$\begin{array}{l}\text { MELD } \\
.291 * \star\end{array}$} & \multirow{2}{*}{$\begin{array}{l}\text { Child } \\
.378^{\star \star}\end{array}$} & \multirow{2}{*}{$\begin{array}{l}\text { Age } \\
.258^{\star}\end{array}$} & \multirow{2}{*}{$\begin{array}{c}\begin{array}{c}\text { Albumin } \\
(\mathrm{g} / \mathrm{dl})\end{array} \\
-.368^{\star \star}\end{array}$} & \multirow{2}{*}{\begin{tabular}{|l} 
INR \\
$.253^{\star}$
\end{tabular}} & \multirow{2}{*}{$\begin{array}{c}\text { Ascites } \\
.303^{\star}\end{array}$} & \multirow{2}{*}{$\begin{array}{c}\begin{array}{c}\mathrm{Hb} \\
(\mathbf{g} / \mathrm{dl})\end{array} \\
.259^{*}\end{array}$} \\
\hline $\begin{array}{l}\text { ASA } \\
\text { Score }\end{array}$ & $\begin{array}{l}\text { Correlation } \\
\text { Coefficient }\end{array}$ & & & & & & & & & & & \\
\hline & $p$-value & .006 & .003 & .016 & .005 & .007 & .003 & .018 & .006 & .021 & .021 & .018 \\
\hline & $\mathrm{N}$ & & & & 53 & & & & 37 & 52 & 5 & \\
\hline
\end{tabular}

$\star \star$. Correlation is significant at the 0.01 level (2-tailed)

*. Correlation is significant at the 0.05 level (2-tailed)

morbidity, identified as $19 \%$ in the study (bleeding, wound suppuration, and intraabdominal abscess- all treated conservatively). The reported conversion rate was $5.45 \%$. Patients who developed postoperative complications had predominantly a postoperative MELD score greater than 13. Apparently, the Child-Pugh score was not significantly correlated with the morbidity, but prospective large cohorts' studies are needed to achieve high statistical significance.

The postoperative in hospital stay, as described in Table 2, positively correlates with Dindo-Clavien classification, open approach emergency surgery, conversion rate, acute cholecystitis, MELD score and the level of total bilirubin, fibrinogen, leucocytes and; it also negatively correlates with the levels of albumin.

Child A and B patients are generally good candidates for laparoscopic cholecystectomy Child $\mathrm{C}$ patients should be converted preoperatively to Child B (10), if possible, or surgery should be avoided, and non-surgical alternatives sought.

Overt portal hypertension syndrome is an absolute contraindication for laparoscopic cholecystectomy (19). An overdeveloped collateral venous circulation is a major problem for the biliary tract surgery in cirrhotic patients, being the most common cause of intra- and post- operative complications. Therefore, when this situation is encountered intraoperatively, most authors recommend conversion to open surgery $(13,20)$. As for the type of approach, cholecystectomy performed in cirrhotic patients, whether open or laparos-copic becomes a difficult procedure $(19,21)$.

In the Department of General Surgery of Fundeni Clinical Institute the preferred approach by most surgeons was laparoscopy, $71.7 \%$, with a conversion rate of $7.4 \%$. This is also due to the vast experience in minimally invasive surgery, being a renowned tertiary center, including minimally invasive surgery for neoplastic pathologies.

Open surgery in cirrhotic patients is associated with high morbidity rates (5-20\%), even in this study it is observed a significant statistical correlation between the type of approach and postoperative complications. The main postoperative complications of open surgery are hemorrhage, decompensa-

Table 2. Kendall's tau_b Correlation Coefficient for Postoperative Days

\begin{tabular}{|c|c|c|c|c|c|c|c|c|c|c|c|}
\hline Kendall's tau_ & & $\begin{array}{l}\text { Dindo } \\
\text { Clavien } \\
\text { Classif. }\end{array}$ & $\begin{array}{l}\text { Surgical } \\
\text { approach }\end{array}$ & $\begin{array}{c}\text { Elective/ } \\
\text { Emergency } \\
\text { surgery }\end{array}$ & Conversion & $\begin{array}{c}\text { Acute } \\
\text { /Chronic }\end{array}$ & MELD & $\begin{array}{c}\text { Total } \\
\text { Bilirubin } \\
(\mathrm{mg} / \mathrm{dl})\end{array}$ & $\begin{array}{c}\text { Albumin } \\
(\mathrm{g} / \mathrm{dl})\end{array}$ & $\begin{array}{c}\text { Fibrinogen } \\
(\mathrm{mg} / \mathrm{dl})\end{array}$ & $\begin{array}{c}\text { Leukocytes } \\
\left(\times 10^{3} / \text { ul) }\right.\end{array}$ \\
\hline \multirow[t]{3}{*}{$\begin{array}{l}\text { Postoperative } \\
\text { Days }\end{array}$} & $\begin{array}{l}\text { Correlation } \\
\text { Coefficient }\end{array}$ & $.430 \star \star$ & $.398 *$ & $.421^{\star \star}$ & $.310^{*}$ & $.412^{\star \star}$ & $.352^{\star *}$ & $.262^{\star \star}$ & $-.247 * \star$ & $.208^{\star}$ & $.216^{\star}$ \\
\hline & $p$-value & .000 & .001 & .000 & 0.30 & .001 & .000 & .008 & .040 & .050 & .028 \\
\hline & $\mathrm{N}$ & & 53 & & 38 & & 53 & & 37 & 46 & 53 \\
\hline
\end{tabular}

**. Correlation is significant at the 0.01 level (2-tailed)

*. Correlation is significant at the 0.05 level (2-tailed) 
tion of cirrhosis with ascites and upper digestive hemorrhage, and wound infections (22). Open cholecystectomy was considered a contra-indication for this fragile group of patients. However, careful assessment of the risk factors and adequate preoperative management may extend these indications. Laparoscopic surgery has indisputable advantages over the classical approach, a fact demonstrated by the literature data $(23,24)$. Thus, laparoscopic cholecystectomy has a better postoperative evolution, with minimal pain, early mobilization, faster resumption of the digestive tolerance and intestinal transit. Postoperative morbidity is lower, with postoperative liver failure much less frequently encountered. In addition, the absence of laparotomy greatly shortens the period of postoperative convalescence, related complications are avoided (hemorrhage, hematomas, infections, eventrations and eviscerations) and minimizes the risk of infected ascites.

With all the technical and tactical progress made over time, and with all the experience gained, laparoscopic cholecystectomy in cirrhotic patients remains one of the difficult laparoscopic surgeries (19) and it can be extremely laborious in acute or scleroatrophic cholecystitis.

Adequate estimation of perioperative mortality and morbidity is generally limited by the retrospective nature of most studies and the patient's selection criteria. The results depend on the severity of the underlying pathologies, the presence of portal hyper-tension, ascites, and associated comorbidities, but also on the type of approach and the degree of emergency
$(25,26)$. Pre-operative identification and correction of pre-existing imbalances (cardiovascular and nutritional) can reduce the risks and decrease the mortality. Preoperative preparation and close monitoring to detect early complications are essential to improve the prognosis of these patients.

The type of approach should be individualized for each patient and should include a multidisciplinary team to improve the liver function and other comorbidities (27). Assessing the severity of cirrhosis using Child and MELD scores allows for a fairly accurate evaluation of perioperative mortality. The literature data shows a 30-day mortality of $10 \%$ for Child A, 30\% for Child B and $76-82 \%$ for Child C, with no significant improvement over time despite the medical progress made $(22,28)$. Regarding the MELD score, a value lower than 11 correlates with a mortality of $5-10 \%, 12-25$ with a mortality of $25-54 \%$ and a value higher than 26 with 90\% postoperative mortality (29). Emergency surgery also correlates with an unfavorable prognosis (29-31).

This study identified that Dindo-Clavien classification, as stated in Table 3, positively corelates with the open approach, emergency surgery, acute cholecystitis, high MELD score and Child score and furthermore with high levels of total bilirubin, high INR, with the presence of ascites and portal hypertension and low levels of hemoglobin.

Despite these difficulties, laparoscopic cholecystectomy proves to be a well-tolerated procedure in carefully selected cirrhotic patients $(23,32,33)$.

Table 3. Kendall's tau_b Correlation Coefficient for Dindo-Clavien Classification

\begin{tabular}{|c|c|c|c|c|c|c|c|c|c|c|c|}
\hline \multicolumn{2}{|c|}{ Kendall's tau_b } & $\begin{array}{c}\begin{array}{r}\text { Surgical } \\
\text { approach }\end{array} \\
-.405^{\star \star}\end{array}$ & $\begin{array}{c}\begin{array}{c}\text { Elective/ } \\
\text { Emergency } \\
\text { surgery }\end{array} \\
.599 * \star\end{array}$ & $\begin{array}{c}\begin{array}{c}\text { Acute } \\
\text { /Chronic }\end{array} \\
.476^{\star \star}\end{array}$ & $\begin{array}{l}\text { MELD } \\
.291^{\star \star}\end{array}$ & $\begin{array}{l}\text { Child } \\
.346^{\star \star}\end{array}$ & \multirow{2}{*}{$\begin{array}{c}\begin{array}{c}\text { Total } \\
\text { Bilirubin } \\
(\mathrm{mg} / \mathrm{dl})\end{array} \\
.220^{\star}\end{array}$} & $\begin{array}{c}\text { INR } \\
.286^{\star \star}\end{array}$ & \multirow{2}{*}{$\begin{array}{c}\text { Ascites } \\
.303^{\star}\end{array}$} & $\begin{array}{c}\begin{array}{c}\mathrm{Hb} \\
(\mathrm{g} / \mathrm{dl})\end{array} \\
-.295^{\star \star}\end{array}$ & \multirow{2}{*}{$\begin{array}{c}\begin{array}{c}\text { Portal } \\
\text { Hypertension }\end{array} \\
.266^{\star}\end{array}$} \\
\hline $\begin{array}{l}\text { Dindo } \\
\text { Clavien } \\
\text { Classif. }\end{array}$ & $\begin{array}{l}\text { Correlation } \\
\text { Coefficient }\end{array}$ & $-.405^{\star \star}$ & $.599 * \star$ & $.476 \star \star$ & $.291^{\star \star}$ & $.346^{\star \star}$ & & $.286^{\star \star}$ & & $-.295^{\star \star}$ & \\
\hline & $p$-value & .002 & .000 & .000 & .008 & .007 & .047 & .010 & .022 & .007 & .044 \\
\hline & $\mathrm{N}$ & & & & 53 & & & 52 & & 53 & \\
\hline
\end{tabular}




\section{Conclusion}

Patients with Child A cirrhosis without portal hypertension have the same indication for elective cholecystectomy as a non-cirrhotic ones, but with increased risks. Therefore, preoperative management should be adapted accordingly. Child B or those with portal hypertension require preoperative evaluation and liver function improvement. For Child $\mathrm{C}$ patients with limited life expectancy, surgery should be avoided, and non-surgical alternatives sought. Emergency surgery, acute cholecystitis and the open approach carry the highest risk for unfavorable results. Giving the retrospective nature of most studies published with small number of patients, further investigations are needed to achieve statistical significance.

\section{Conflict of Interest}

The authors declare no conflicts of interests.

\section{Author's Contributions}

Vlad-Costin Ilie and Mohammed Alabed Alhamid share first authorship.

\section{Ethics Approval}

Approval from the Review Board was obtained for using patients data in the present study and informed consent was obtained from all the patients who underwent surgery in our institution.

\section{References}

1. Nusrat S, Khan MS, Fazili J, Madhoun MF. Cirrhosis and its complications: evidence based treatment. World J Gastroenterol. 2014;20(18):5442-60.

2. Strömberg J, Hammarqvist F, Sadr-Azodi O, Sandblom G. Cholecystectomy in Patients with Liver Cirrhosis. Gastroenterol Res Pract. 2015;2015:783823.

3. Acalovschi M. Gallstones in patients with liver cirrhosis: incidence, etiology, clinical and therapeutical aspects. World J Gastroenterol. 2014;20(23):7277-85.

4. Keus F, Gooszen HG, van Laarhoven CJhm. Open, small-incision, or laparoscopic cholecystectomy for patients with symptomatic cholecystolithiasis. An overview of Cochrane Hepato-Biliary Group reviews. Cochrane Database Syst Rev. 2010;2010(1):CD008318.
5. Delis S, Bakoyiannis A, Madariaga J, Bramis J, Tassopoulos N, Dervenis C. Laparoscopic cholecystectomy in cirrhotic patients: the value of MELD score and Child-Pugh classification in predicting outcome. Surg Endosc. 2010;24(2):407-12. Epub 2009 Jun 24

6. Lledó JB, Ibañez JC, García Mayor L, Juan MB. Laparoscopic cholecystectomy and liver cirrhosis. Surg Laparosc Endosc Percutan Tech. 2011;21(6):391-5.

7. Laurence JM, Tran PD, Richardson AJ, Pleass HCC, Lam VWT. Laparoscopic or open cholecystectomy in cirrhosis: a systematic review of outcomes and meta-analysis of randomized trials. HPB (Oxford). 2012;14(3):153-61.

8. Bloch RS, Allaben RD, Walt AJ. Cholecystectomy in patients with cirrhosis. A surgical challenge. Arch Surg. 1985;120(6):669-72.

9. Castaing D, Houssin D, Lemoine J, Bismuth H. Surgical management of gallstones in cirrhotic patients. Am J Surg. 1983; 146(3):310-3

10. Leone N, Garino M, De Paolis P, Pellicano R, Fronda GR, Rizzetto M. Laparoscopic cholecystectomy in cirrhotic patients. Dig Surg. 2001;18(6):449-52.

11. McSherry CK, Glenn F. The incidence and causes of death following surgery for nonmalignant biliary tract disease. Ann Surg. 1980;191(3):271-5

12. Deziel DJ, Millikan KW, Economou SG, Doolas A, Ko ST, Airan MC. Complications of laparoscopic cholecystectomy: a national survey of 4,292 hospitals and an analysis of 77,604 cases. Am J Surg. 1993:165(1):9-14.

13. Morino M, Cavuoti G, Miglietta C, Giraudo G, Simone P. Laparoscopic cholecystectomy in cirrhosis: contraindication or privileged indication? Surg Laparosc Endosc Percutan Tech. 2000; 10(6):360-3.

14. National Institutes of Health Consensus Development Conference Statement on Gallstones and Laparoscopic Cholecystectomy. Am J Surg. 1993;165(4):390-8.

15. Cuschieri A, Dubois F, Mouiel J, Mouret P, Becker H, Buess G, Trede $\mathrm{M}$, Troidl $\mathrm{H}$. The European experience with laparoscopic cholecystectomy. Am J Surg. 1991;161(3):385-7.

16. Puggioni A, Wong LL. A metaanalysis of laparoscopic cholecystectomy in patients with cirrhosis. J Am Coll Surg. 2003;197(6): 921-6.

17. Currò G, Iapichino G, Melita G, Lorenzini C, Cucinotta E. Laparoscopic cholecystectomy in Child-Pugh class $C$ cirrhotic patients. JSLS. 2005;9(3):311-5.

18. Machado NO. Laparoscopic cholecystectomy in cirrhotics. JSLS. 2012;16(3):392-400.

19. Bala O, Duca S, lancu C, Puia C, Toganel D, Paraian I, et al. Colecistectomia laparoscopică la pacientii cu ciroză hepatică. Romanian Journal of Gastroenterology. 1997;6(Suppl. 1):12-14.

20. Duca S. Colecistectomia laparoscopică la cirotici. În "Chirurgia laparoscopică a căilor biliare. Cluj-Napoca: Ed. Dacia; 1994. p. 102-3.

21. Doberneck RC, Sterling WA Jr, Allison DC. Morbidity and mortality after operation in nonbleeding cirrhotic patients. Am J Surg. 1983; 146(3):306-9

22. Garrison RN, Cryer HM, Howard DA, Polk HC Jr. Clarification of risk factors for abdominal operations in patients with hepatic cirrhosis. Ann Surg. 1984;199(6):648-55.

23. Yerdel MA, Tsuge H, Mimura H, Sakagami K, Mori M, Orita K. Laparoscopic cholecystectomy in cirrhotic patients: expanding indications. Surg Laparosc Endosc. 1993:3(3):180-3

24. Thompson JS. Is Laparoscopic Cholecystectomy Safe in Cirrhotic Patients? Am J Gastroenterology. 1999;94(5):1138.

25. de Goede B, Klitsie PJ, Lange JF, Metselaar HJ, Kazemier G. Morbidity and mortality related to non-hepatic surgery in patients with liver cirrhosis: a systematic review. Best Pract Res Clin Gastroenterol. 2012;26(1):47-59.

26. Sabbagh C, Fuks D, Regimbeau JM. Non-hepatic gastrointestinal surgery in patients with cirrhosis. J Visc Surg. 2014;151(3):203-11.

27. Nicoll A. Surgical risk in patients with cirrhosis. J Gastroenterol 
Hepatol. 2012;27(10):1569-75.

28. Mansour A, Watson W, Shayani V, Pickleman J. Abdominal operations in patients with cirrhosis: still a major surgical challenge. Surgery. 1997;122(4):730-5; discussion 735-6.

29. Telem DA, Schiano T, Goldstone R, Han DK, Buch KE, Chin EH, Nguyen SQ, Divino CM. Factors that predict outcome of abdominal operations in patients with advanced cirrhosis. Clin Gastroenterol Hepatol. 2010;8(5):451-7, quiz e58.

30. Meunier K, Mucci S, Quentin V, Azoulay R, Arnaud JP, Hamy A. Colorectal surgery in cirrhotic patients: assessment of operative morbidity and mortality. Dis Colon Rectum. 2008;51(8):1225-31.
31. Hoteit MA, Ghazale AH, Bain AJ, Rosenberg ES, Easley KA, Anania FA, Rutherford RE. Model for end-stage liver disease score versus Child score in predicting the outcome of surgical procedures in patients with cirrhosis. World J Gastroenterol. 2008;14(11): 1774-80.

32. Friel CM, Stack J, Forse A, Babineau TJ. Laparoscopic cholecystectomy in patients with hepatic cirrhosis: a five-year experience. $\mathrm{J}$ Gastrointest Surg. 1999;3(3):286-91.

33. Sleeman D, Namias N, Levi D, Ward FC, Vozenilek J, Silva R, et al. Laparoscopic cholecystectomy in cirrhotic patients. J Am Coll Surg. 1998;187(4):400-3. 